\title{
Otonomi Kolektif dan Operasionalisasi Kesadaran Publik dalam Gerakan Solidaritas Pangan Jogja (SPJ)
}

\author{
Didid Haryadi \\ Tenaga Pengajar Sosiologi FISIP Universitas Nasional \\ Indonesia \\ haryadidid@gmail.com
}

\section{Keywords:}

Solidaritas Pangan

Jogja; Social

Movement; Social

Capital; Collective

Action

Solidaritas Pangan

Jogja; Gerakan

Sosial; Modal

Sosial; Tindakan

Kolektif

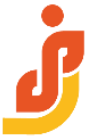

BRAWIJAYA JOURNAL of SOCIAL SCIENCE

Vol. 1, No. 1,2021

DOI:

https://doi.org/10. 21776/ub.bjss.2021 .001 .01 .4

Submitted:2021-11-15 Accepted:2021-12-05

\section{Abstract}

The Covid-19 pandemic has changed the pattern of interaction and socialization of community members. One of them is an effort to build awareness and social solidarity to help each other, especially in the dimension of domestic needs, such as food fulfillment. The Jogja Food Solidarity Movement (Solidaritas Pangan Jogja/SPJ) represents a collective action that grew because of the awareness of individuals and groups to distribute food aid to informal workers and marginalized groups in Yogyakarta. This paper examines two main points; first, how SPJ manages its social network pattern during the Covid-19 pandemic. Second, why the SPJ movement is autonomous. Using a qualitative approach and case study method, this paper finds that the SPJ movement maximizes social capital through networks and social support from non-governmental institutions, activist groups, artists, students, and the Kulon Progo Coastal Farmers Association (Paguyuban Petani Lahan Pantai/PPLP) to distribute food. to the public. The SPJ movement is formed organically, autonomously and rationally, which is a manifestation of systematically organized collective action. Through the analysis of the Resource Mobilization Theory (Teori Mobilisasi Sumber Daya/TMSD), the SPJ movement is needed to create and show collective dissatisfaction, especially during the Covid-19 pandemic, namely without which dissatisfaction is only at the individual level.

\section{Abstrak}

Pandemi Covid-19 telah mengubah pola interaksi dan sosialisasi anggota masyarakat. Salah satunya adalah upaya membangun kesadaran dan solidaritas sosial untuk saling membantu khususnya dalam dimensi kebutuhan domestik, seperti pemenuhan pangan. Gerakan Solidaritas Pangan Jogja (SPJ) merupakan representasi tindakan kolektif yang tumbuh karena adanya kesadaran individu dan kelompok untuk mendistribusikan bantuan makanan 
kepada para pekerja informal dan kelompok marjinal di Yogyakarta. Tulisan ini menelaah dua hal utama; pertama, bagaimana SPJ mengelola pola jaringan sosialnya selama pandemi Covid-19. Kedua, mengapa gerakan SPJ bersifat otonom. Dengan menggunakan pendekatan kualitatif dan metode studi kasus, tulisan ini menemukan bahwa gerakan SPJ memaksimalkan modal sosial melalui jaringan dan dukungan sosial dari lembaga-lembaga non-pemerintah, kelompok aktivis, seniman, mahasiswa, serta Paguyuban Petani Lahan Pantai (PPLP) Kulonprogo untuk mendistribusikan makanan kepada publik. Gerakan SPJ terbentuk secara organik, bersifat otonom dan rasional, yakni suatu manifestasi tindakan kolektif yang terorganisasi dengan sistematis. Melalui analisis Teori Mobilisasi Sumber Daya (TMSD), gerakan SPJ diperlukan untuk menciptakan dan menunjukkan ketidakpuasan kolektif khususnya pada masa pandemi Covid-19, yang tanpa hal tersebut ketidakpuasan hanya berada pada level individu saja.

\section{Pendahuluan}

Pandemi Covid-19 memunculkan fenomena adanya kesadaran publik yang berbasis pada solidaritas sosial warga untuk saling membantu memenuhi kebutuhan pangan. Situasi ini muncul di tengah ketidakpastian situasi pandemi yang berdampak secara langsung pada dimensi domestik dan kesejahteraan sosial. Pada April 2020, Kementerian Ketenagakerjaan Republik Indonesia merilis jumlah pekerja yang terdampak Covid-19 mencapai 2.084 .593 pekerja. Dari jumlah tersebut, sebanyak 1.304.777 pekerja mengalami Pemutusan Hubungan Kerja (PHK) (Kementerian Ketenagakerjaan, 2020).

Sektor formal dan informal turut merasakan dampak buruk akibat pandemi Covid19. Riset LIPI (Lembaga Ilmu Pengetahuan Indonesia) bersama Asosiasi Business Development Services Indonesia pada 2020 mengindikasikan seluruh bisnis mikro, kecil dan menengah (UMKM) melaporkan adanya penurunan penjualan yang sangat signifikan yakni menurunnya laba usaha (Ahmada et al., 2020).

Salah satu upaya yang dilakukan oleh pemerintah untuk mengatasi masalah tersebut adalah menerapkan kebijakan program Jaring Pengaman Sosial (JPS). Lebih lanjut, beberapa strategi dalam JPS antara lain 1) penambahan penerima dan besaran manfaat Program Keluarga Harapan (PKH) dan Kartu Sembako, 2) Kartu Prakerja, 3) Subsidi biaya listrik, 4) Operasi pasar dan logistik, 5) Pembayaran kredit bagi kelompok informal (Knowledge Sector Initiative, 2020). Meskipun demikian, dinamika yang terjadi di lapangan secara tidak langsung mempengaruhi efektivitas kebijakan tersebut. Riset yang dilakukan oleh Saiful Mujani Research \& Consulting (SMRC, 2020) bersama Indikator Politik Indonesia (2020) menemukan bahwa bantuan sosial yang diberikan oleh pemerintah belum tepat sasaran. Misalnya, penggunaan data yang tidak valid, permasalahan aksesibilitas untuk memperoleh bantuan, hingga adanya pungutan liar. Selain itu, polemik Kartu Prakerja seperti adanya dugaan konflik kepentingan, bentuk 
insentif, efektivitas program, penerima kartu, hingga terkait efisiensi anggaran (Indonesia Corruption Wacth, 2020).

Studi Sumner (Sumner et al., 2020) menemukan bahwa pandemi Covid-19 berpotensi meningkatkan jumlah kelompok masyarakat miskin baru sebanyak 8,5 juta orang dengan asumsi pertumbuhan ekonomi tahunan pada angka 1\% (Suryahadi et al., 2020). Sementara itu, riset Alkire (Alkire et al., 2020) menegaskan adanya hubungan yang erat antar jumlah kelompok berisiko terinfeksi Covid-19 terhadap jumlah orang yang hidup dalam kategori miskin. Dalam konteks ini, masyarakat miskin dihadapkan dengan realitas ancaman dimensi kesehatan, ekonomi, dan pemenuhan kebutuhan pangan.

Dalam konteks gerakan dukungan sosial, di Yogyakarta, Kepala Desa Sardonoharjo Herjuno Wiwoho menyatakan dirinya berinisiatif mendorong warga untuk memiliki lumbung pangan di wilayah masing-masing, selain juga membangun lumbung pangan sendiri di tingkat desa. Lumbung pangan dimaksudkan sebagai jaring pengaman sosial terutama bagi mereka yang kurang mampu dan harus mengisolasi diri secara mandiri. Selain donasi dari warga, ada pula dana lain yang disisihkan dari Dana Desa.

Inisiatif serupa juga hadir dari Organisasi Masyarakat (Ormas) Muhammadiyah yang ikut menggerakkan pengaktifan lumbung pangan di tengah pandemi melalui Lembaga Zakat Infaq dan Shadaqah Muhammadiyah (Lazismu). Ketua Lazismu, Hilman Latief menjelaskan bahwa konsep lumbung itu ada beberapa jenis. Pertama ada lumbung yang identik dengan gudang penyimpanan pangan dan hanya dapat dimanfaatkan oleh satu komunitas dalam keadaan mendesak, misalnya paceklik. Kedua, lumbung dapat juga berbentuk kerja sama pengelolaan bahan pangan. Yang dilakukan oleh Muhammadiyah dan Lazismu adalah membangun kerja sama dengan para petani dan peternak. Organisasi lain yang melakukan hal tersebut adalah Konsorsium Pembaruan Agraria (KPA) yaitu organisasi yang terdiri dari serikat tani, masyarakat adat dan nelayan dan kerap berkampanye soal 'reforma agraria sejati' yang bertujuan memobilisasi hasil panen para petani yang harga jualnya turun karena terdampak pandemi Covid-19.

Sekjen KPA Dewi Kartika menjelaskan ada dua konsep lumbung agraria yang dijalankan, yakni melalui insentif dan melalui donasi. Mekanisme pertama, KPA mengumpulkan hasil panen petani kemudian didistribusikan. Distribusi ini tidak dibuka secara umum tetapi hanya kepada jaringan serikat buruh, komunitas sektor informal, dan kaum miskin kota yang paling terdampak pandemi Covid-19. Mekanisme kedua, lumbung agraria berbasis donasi dari para petani yang memberikan secara cuma-cuma hasil buminya untuk diberikan kepada yang berhak.

Seturut hal tersebut, salah satu gerakan alternatif lainnya yang berasal dari inisiatif warga adalah Solidaritas Pangan Jogja (SPJ). Gerakan ini berakar dari semangat yang diinisiasi oleh Ita bersama kedua putrinya untuk memberikan bantuan kepada mereka yang tak berdaya di tengah pandemi Covid-19, khususnya kelompok rentan dan pekerja sektor informal. Selanjutnya SPJ membuka jaringan pekerja sosial lainnya, antara lain Lembaga Bantuan Hukum (LBH) Yogyakarta, Aliansi Jurnalis Independen (AJI) Yogyakarta, Wahana Lingkungan Hidup (Walhi) Yogyakarta, dan Social Movement 
Institute (SMI) yang mayoritas anggotanya adalah aktivis mahasiswa (Haryadi \& Malitasari, 2020).

Kurang maksimalnya implementasi kebijakan negara dalam penanggulangan pandemi Covid-19 memunculkan gerakan inisiatif dari warga dengan semangat saling membantu. Biasanya, model gerakannya berbentuk komunitas dan terbuka kepada semua kelompok. Secara sosiologis, gerakan organik tersebut dapat dikategorikan sebagai bentuk lain daripada jaringan dukungan sosial. Canton (Canton, 2018), Hill (Hill et al., 2021), Sotiropoulos \& Bourikos (Sotiropoulos \& Bourikos, 2014) mencatat dalam masa krisis, jaringan dukungan sosial dapat menjadi sebuah jaring pengaman di luar negara. Kehadirannya berperan untuk menjaga para kelompok rentan dan terdampak agar tidak masuk dalam kondisi miskin. Ringkasnya, risiko yang diakibatkan dari krisis dapat ditanggulangi melalui dukungan sosial.

Berdasarkan latar belakang tersebut, tulisan ini berusaha menjelaskan rumusan masalah sebagai berikut:

1. Bagaimana SPJ mengelola pola jaringan sosialnya selama pandemi Covid-19?

2. Mengapa gerakan SPJ bersifat otonom?

\section{Metode Penelitian}

Tulisan ini menggunakan metode penelitian kualitatif dengan mengambil studi kasus pada gerakan Solidaritas Pangan Jogja (SPJ). Penelitian kualitatif tidak hanya upaya mendeskripsikan data, akan tetapi dengan mengutamakan hasil pengumpulan data yang shahih dengan kriteria; wawancara mendalam, observasi partisipasi, studi dokumentasi, dan triangulasi data (Moleong, 2019).

Proses deskripsi dan analisis data melalui beberapa tahapan, pertama penyajian data, reduksi data, refleksi data, kajian emik (fenomena sosial berdasarkan penilaian dari masyarakat itu sendiri) dan etik (fenomena sosial berdasarkan penilaian di luar masyarakat itu sendiri) terhadap data, serta pengambilan kesimpulan. Sesuai dengan paradigma dalam penelitian kualitatif, bahwa peneliti akan mencoba memahami bagaimana individu meresapi makna dari dunia sekitarnya dan melakukan konstruksi pandangan tentang kehidupan sosial. Tujuannya, memberikan penjelasan (eksplanatif); dengan memahami ciri dan hubungan sistematis fenomena berdasarkan fakta di lapangan. Sementara itu, proses analisis data akan dilakukan secara induktif, yakni menampilkan informasi latar penelitian secara utuh serta mampu menemukan pengaruh bersama yang dapat mempertajam hubungan antar konsep yang menjadi fokus penelitian.

\section{Hasil dan Pembahasan}

\subsection{Solidaritas Pangan Jogja (SPJ)}

Pemilihan Pemberlakuan kebijakan PSBB secara langsung telah memberikan dampak yang signifikan terhadap sektor perekonomian yang bergerak pada bidang 
manufaktur, pariwisata, perhotelan, dan transportasi. Selain itu, trauma dan kehilangan orang-orang yang disayangi, ketidakpastian kapan pandemi akan berakhir menyebabkan ketakutan, kepanikan, yang mempengaruhi kesehatan mental manusia (Sari, 2020). Negara atau pemerintah, dalam hal ini dinilai lambat menangani pandemi Covid-19 beserta masalah yang ditimbulkannya. Akan tetapi, terlepas dari hal tersebut solidaritas sosial yang ada di masyarakat semakin meningkat, yang mana solidaritas ini memiliki kaitan yang erat dengan karakter yang dimiliki oleh masyarakat itu sendiri. Solidaritas sosial yang ada di masyarakat pada masa pademi ini dapat mendorong masyarakat untuk mentaati himbauan yang diberikan pemerintah dan juga menyumbangkan sebagian dari apa yang mereka miliki untuk membantu satu sama lain.

Arie Sudjito berpendapat bahwa solidaritas yang ditujukan saat menghadapi situasi pandemi Covid-19 diantaranya ialah inisiasi masyarakat pada level komunitas untuk melakukan perlindungan diri, baik terkait kesehatan, keamanan maupun kenyamanan. Tidak hanya terkait masalah kesehatan, ada juga berbagai gerakan kemanusiaan yang berbasis sosial ekonomi, mulai dari charity hingga jaminan sosial. Arie menegaskan bahwa solidaritas sosial akibat Covid-19 ini secara spontan entah mereka melihat dari televisi dan media sosial lain yang kaitannya dengan perlindungan diri dan kesehatan. Jadi, kalau di pemerintah membuat PSBB maka di tingkat lokal mereka membuat perlindungan diri, dengan bersih lingkungan, membagi hand sanitizer, tidak lagi menunggu dari pemerintah. Penjahit-penjahit pun kemudian membuat masker, membuat slogan ajakan stay at home dan itu merupakan ajakan yang nyata.

Salah satu solidaritas sosial yang berkembang dalam masa pandemi ini ialah Solidaritas Pangan Jogja (SPJ). Anggota yang terlibat dalam solidaritas ini terdiri dari berbagai kalangan, mulai dari mahasiswa, LSM (Lembaga Swadaya Masyarakat), organisasi masyarakat sipil, serta individu-individu yang ingin ikut terlibat dalam kegiatan tersebut. Lutfi, salah satu anggota aktif SPJ menuturkan latar belakang temanteman SPJ sangat beragam, ada yang dari mahasiswa, pekerja perusahaan, pengusaha UKM (Usaha Kecil Menengah), juga ada yang memiliki latar belakang lain misalnya fokus di lembaga bantuan hukum. Setelah resmi terbentuk, langkah awal yang diambil oleh solidaritas ini ialah dengan membangun dapur umum di Posko Gamping dan Seyegan, Kabupaten Sleman dan Posko Prawirotaman, Kota Yogyakarta.

Sasaran dari pemberian makanan gratis ini ialah para pekerja informal. Sejak saat pertama didirikan hingga saat ini, dapur umum yang dibuat oleh SPJ jumlahnya sudah bertambah menjadi 11 posko. Setiap posko ini memiliki sasaran yang berbeda-beda. Seperti yang disampaikan oleh Lutfi, target bantuan yang didistribusikan oleh SPJ yaitu pekerja informal yang sangat terdampak dan masih harus terus bekerja di jalanan. Karena fokus utama kami adalah makanan matang, jadi ya mereka yang tetap bekerja di jalanan seperti bapak-bapak tukang becak, para pemulung, para pedagang kecil, buruh gendong, dan lain-lain. Selain itu, distribusi juga diberikan kepada para tukang ojek. Bentuk aktualisasi yang dilakukan oleh SPJ merupakan bagian daripada gerakan sosial organik yang mencoba mematahkan dominasi otoritas formal yang berada pada level makro. 
Diketahui bahwa pasca gelombang reformasi 1998 telah muncul organisasi masyarakat yang melakukan advokasi terhadap isu-isu sosial, ekonomi, politik, dan lingkungan. Bahkan cukup banyak juga organisasi masyarakat yang akhirnya memilih bertransformasi menjadi partai politik. Kartodirdjo menjelaskan, gerakan-gerakan sosial yang berlangsung di era transisi tersebut bercorak nativisme, mesianisme, millenarianism, prophetisme, dan revivalisme (Sartono Kartodirdjo, 1984). Ideologi nativisme dan mesianisme merupakan pilihan kolektif dalam merespon semakin menguatnya rasionalisme dalam relasi sosial. Pudarnya ikatan sosial tradisional, seperti ikatan kedaerahan dan lembaga sosial yang memberi jaminan dan perlindungan masyarakat kelas bawah menyebabkan kelas ini bukan hanya disorientasi, tetapi juga mengalami tekanan sosial. Mereka tidak lagi terintegrasi dengan masyarakat secara keseluruhan dan belum berhasil membangun ikatan sosial yang mampu mewadahi apalagi mengaktualisasikannya.

Sejalan dengan hal tersebut, Peter Barke mencatat, pada era transisi kapitalisme yang ditandai dengan semakin meluasnya peranan ekonomi uang, meluasnya rasionalisme dan munculnya lembaga-lembaga baru seperti sekolah, rumah sakit, perbankan, pegadaian, pasar dan organisasi sosial, aksi-aksi kolektif dilakukan baik untuk memulai suatu perubahan atau sebagai reaksi terhadap perubahan yang sedang terjadi

\subsection{Pola Gerakan Solidaritas Pangan Jogja}

Permasalahan Upaya distribusi makanan dilakukan oleh SPJ dengan menentukan lokasi yang tepat. Misalnya, memanfaatkan posko kampung pemulung di Wonocatur, Bantul. Posko Piyungan, Bantul dikhususkan untuk para lanjut usia yang menempati lima RT (Rukun Tetangga) di wilayah sana.

Selanjutnya, ada posko Ngadiwinatan, Yogyakarta, yang digunakan untuk gudang logistik. Di posko tersebut makanan dipesan dan dibeli dari warung-warung yang kehilangan penghasilan akibat pandemi Covid-19. Situasi ini menggambarkan munculnya upaya untuk memberdayakan pedagang kecil sekaligus membangun kesadaran kolektif untuk saling membantu satu sama lain.

SPJ melakukan distribusi makanan dengan sistem 'door to door'-mendatangi para keluarga miskin yang sebelumnya telah didata oleh anggota, seperti yang dijelaskan Lutfi:

"kami datangi rumahnya satu per satu berangkat dari survei yang kami lakukan sambil membagikan distribusi bahan makanan yang sudah, distribusi makanan yang telah dimasak".

Sementara itu, posko Caturtunggal dimanfaatkan sebagai dapur umum dan gudang logistik. Posko asisten rumah tangga (ART) di Balirejo, Yogyakarta memasak makanan untuk para buruh gendong pasar. Posko Bongsuwung di barat Stasiun Tugu Yogyakarta untuk pemulung, pedagang kaki lima, serta pekerja seks komersial yang kehilangan 
pendapatan. Selanjutnya, posko Kotagede menyediakan makanan untuk para lansia. Dalam sehari, masing-masing posko mampu menghasilkan 100 - 150 nasi bungkus.

Aktivitas SPJ dibantu oleh para relawan yang bekerja secara kolektif untuk memastikan kegiatan dapat berjalan dengan lancar. Tugas dari para relawan yang terlibat dalam solidaritas ini ialah memasak, mengemas, dan mendistribusikannya ke mereka yang berhak menerimanya. Semua proses tersebut tentunya dilakukan dengan tetap mematuhi protokol Covid-19, menjaga jarak, mencuci tangan, menggunakan masker, dan sebagainya.

Pola distribusi pangan yang dilakukan oleh SPJ adalah dengan mengkategorikan dua jenis dapur, yakni dapur umum dan dapur komunitas. Dapur Umum adalah dapur yang memproduksi dan mendistribusikan makanan kepada pekerja informal di jalan dan ruang publik. Sementara itu, dapur komunitas adalah dapur yang dikelola oleh warga atau komunitas untuk memenuhi kebutuhan makanan, khususnya bagi kelompok rentan di wilayahnya masing-masing.

Tabel 1. Lokasi Dapur Umum dan Dapur Komunitas SPJ

\begin{tabular}{|c|c|c|c|}
\hline No & Nama Dapur & Jenis Dapur & Alamat \\
\hline 1 & Dapur Pasar Gamping & Umum & $\begin{array}{c}\text { Perumahan } \\
\text { Ambarketawang Permai, } \\
\text { Gamping Kidul, RT 3/RW } \\
\text { 19, Gamping, Sleman }\end{array}$ \\
\hline
\end{tabular}

\begin{tabular}{|c|c|c|c|}
\hline 2 & Dapur Prawirotama & Umum & $\begin{array}{c}\text { Reene'o Guesthouse, } \\
\text { Brontokusuman, MG } \\
\text { III/379, Yogyakarta }\end{array}$ \\
\hline
\end{tabular}

\begin{tabular}{|c|c|c|c|}
\hline 3 & Dapur Seyegan & Umum & $\begin{array}{c}\text { Araya Stabel, Dusun } \\
\text { Klaci II, Desa } \\
\text { Margoluwih, Seyegan, } \\
\text { Sleman }\end{array}$ \\
\hline 4 & Dapur Wonocatur & Komunitas & $\begin{array}{c}\text { Gang Rukun, Jalan } \\
\text { Wonocatur, RT 4/RW 2, } \\
\text { Yogyakarta }\end{array}$ \\
\hline 5 & Dapur Cepokojajar & Komunitas & $\begin{array}{c}\text { Kediaman Pak Slamet, } \\
\text { Pak Eko, Pak Yono, } \\
\text { Cepokojajar, RT } 2 \\
\text { Sitimulyo, Piyungan, } \\
\text { Bantul }\end{array}$ \\
\hline
\end{tabular}


Rusunawa Otonomi Kolektif dan Operasionalisasi Kesadaran Publik dalam Gerakan Solidaritas Pangan Jogja|

\begin{tabular}{cccc}
\hline 6 & Dapur Ngadiwinatan & Umum & $\begin{array}{c}\text { Ngadiwinatan } 1 / 249, \\
\text { Yogyakarta }\end{array}$ \\
\hline 7 & Dapur Caturtunggal & Umum & $\begin{array}{c}\text { Jalan Wirajaya No.135, } \\
\text { Gejayan, Condongcatur, } \\
\text { Depok, Sleman }\end{array}$ \\
\end{tabular}

\begin{tabular}{|c|c|c|c|}
\hline 8 & Dapur Balirejo & Komunitas & $\begin{array}{l}\text { Gang Kecana, Muja } \\
\text { Maju, Yogyakarta }\end{array}$ \\
\hline 9 & Dapur Bongsuwung & Komunitas & $\begin{array}{c}\text { Bongsuwung, } \\
\text { Gedongtengen, Barat } \\
\text { Stasiun Tugu, Yogyakarta }\end{array}$ \\
\hline 10 & Dapur Keparakan & Komunitas & $\begin{array}{c}\text { Keparakan Kidul, } \\
\text { Kotagede, Yogyakarta }\end{array}$ \\
\hline 11 & Dapur Sembungan & Umum & $\begin{array}{l}\text { Gang Ramawijaya, } \\
\text { Sumbungan, Sumbungan, } \\
\text { RT 33, Bangunjiwo, } \\
\text { Kasihan, Bantul }\end{array}$ \\
\hline
\end{tabular}

Sumber: Solidaritas Pangan Jogja, 2020 (dalam Ahmada et al., 2020)

Kathy S. Stolley, dalam karyanya 'The Basic of Sociology' menjelaskan bahwa solidaritas yang kolektif dan dalam jumlah yang besar terkadang dapat memicu tanggapan yang negatif dari masyarakat. Sebaliknya, mereka melihat perilaku kolektif sebagai aktivitas spontan yang melibatkan orang banyak dan melanggar norma-norma yang sudah mapan. Perilaku ini terjadi ketika orang-orang bereaksi terhadap sesuatu yang baru atau asing. Hasilnya, mungkin akan muncul perubahan kecil, tidak terduga dalam jangka pendek. Perilaku itu juga dapat mengarah pada gerakan sosial yang terorganisir dan bertujuan menciptakan perubahan sosial (Stolley, 2005).

Sementara itu, Turner dan Killian dalam gagasannya mengenai 'emergent-norm theory', menyatakan teori norma hadir dengan mengambil perspektif interaksi sosial dari perilaku orang banyak. Menurut teori ini, norma-norma baru yang berkembang (muncul) ketika ada peristiwa yang sedang terjadi. Selain itu, teori ini berpijak pada instrumen komunikasi dan isyarat yang ada di dalam anggota sebuah kelompok. Mereka dipandu oleh koordinator untuk menjamin aktivitas dapat berlangsung secara sistematis. 
Turner dan Killain menambahkan bahwa perilaku anggota berfungsi sebagai panduan untuk tindakan sosial bagi anggota masyarakat lain yang berada di luar kelompok mereka. Anggota yang tergabung dalam perilaku kolektif menafsirkan peristiwa, mendefinisikan kembali situasi, dan mengikuti norma-norma yang dibangun dari perilaku yang 'situasional' atau insidental. Secara ringkas, inisiatif yang dilakukan oleh SPJ merepresentasikan konsep solidaritas dan tindakan kolektif yang bertujuan memberikan dukungan sosial kepada masyarakat.

\subsection{Semangat Gerakan SPJ}

Menurut Michael Useem, mendefinisikan gerakan sosial sebagai tindakan kolektif terorganisasi, yang dimaksudkan untuk mengadakan perubahan sosial. John McCarthy dan Mayer Zald mendefinisikan gerakan sosial sebagai upaya terorganisasi untuk mengadakan perubahan di dalam distribusi hal-hal apa pun yang bernilai secara sosial. Sementara itu, menurut Charles Tilly gerakan sosial adalah upaya-upaya mengadakan perubahan lewat interaksi yang mengandung perseteruan dan berkelanjutan di antara warga negara dan negara (Wiktorowicz, 2004).

David Meyer dan Sidney Tarrow dalam karyanya 'Social Movement Society' (1998) bahwa gerakan sosial adalah tantangan-tantangan bersama, yang didasarkan atas tujuan dan solidaritas bersama, dalam interaksi yang berkelanjutan dengan kelompok elit, saingan atau musuh, dan pemegang otoritas (Tarrow, 2011).

Lebih lanjut, Tarrow menegaskan bahwa gerakan-gerakan sosial adalah bentuk paling modern dari politik perseteruan (contentious politics), yang terjadi ketika orangorang biasa seringkali dalam kerja sama dengan warga negara yang lebih berpengaruh, bersama-sama menggalang kekuatan dalam konfrontasi kolektif mereka melawan kelompok elit, pemegang otoritas, dan musuh-musuh politik.

Kemunculan SPJ merupakan gambaran minor bahwa terdapat kekecewaan yang dirasakan oleh warga negara terhadap kebijakan penanganan pandemi Covid-19 yang dilakukan oleh pemerintah. Bahwa perasaan ketidakadilan atau ketidakpuasan sosial adalah faktor-faktor yang melatarbelakanginya. Namun, sebelum gerakan SPJ muncul, bukan berarti kecemasan dan kekhawatiran terhadap distribusi kesejahteraan sosial tidak dirasakan. Justru, ketiadaan gerakan tidak mengindikasikan ketiadaan penindasan atau ketidakpuasan kolektif. Dengan kata lain, orang-orang tidak bergerak bukan karena mereka semuanya sudah merasa Bahagia, sudah tidak lagi merasa dizalimi dan puas. Lebih jauh, mereka melihat bahwa ketidakpuasan individual bukanlah faktor penjelas kunci dan bahwa gerakan-gerakan sosial bukanlah respons atas fenomena psikologis melainkan suatu respons politik atas masalah-masalah yang dihadapi. Dalam ruang lingkup teori gerakan sosial, pandangan seperti ini seturut dengan konsep dalam Teori Mobilisasi Sumber Daya (TMSD/Resources Mobilization Theory) ingin menjawab 'masalah pendompleng bebas' (free rider problem) yang biasanya muncul di tengah aktivis gerakan, bahwa 'kalau kepentingan saya sudah diwakili oleh orang-orang tertentu yang bersedia ikut di dalam gerakan, mengapa pula saya perlu repot-repot dan mengambil 
resiko ikut dalam gerakan' (Wiktorowicz, 2004). Menurut John D. McCharty (1996), keunggulan TMSD adalah keragaman struktur-struktur mobilisasi dari jaringan informal keluarga dan perkawanan hingga organisasi-organisasi formal seperti gereja dan asosiasi-asosiasi professional.

Dalam konteks perjuangan dan advokasi melalui distribusi pangan yang dilakukan oleh SPJ, dimensi dan ruang kerja TMSD menemui bentuknya yang sangat natural. Bahwa TMSD melihat gerakan tersebut sebagai sesuatu yang rasional, suatu manifestasi tindakan kolektif yang terorganisasi. Dalam TMSD, sumber daya dan struktur mobilisasi, seperti organisasi gerakan sosial yang formal, diperlukan untuk menciptakan ketidakpuasan kolektif yang tanpa hal tersebut ketidakpuasan hanya berada pada level individu saja.

Salah satu solusi yang diberikan oleh teori TMSD dalam mencegah munculnya free rider adalah memunculkan 'para wirausahawan politik' (political entrepreneurs) kelompok yang bekerja secara profesional dengan tumbuhnya organisasi gerakan sosial (OGS)-yang mengorganisasikan dan 'berbicara atas nama' mereka yang termarjinalisasi. Contohnya, SPJ menolak penghargaan yang diberikan oleh negara, yaitu melalui Kementerian Pendayagunaan Aparatur Negara dan Reformasi Birokrasi (Kemenpan-RB). Secara khusus, penolakan tersebut mencitrakan otonomi gerakan SPJ yang lahir, tumbuh dan berkembang secara organik bersama masyarakat.

Beberapa pertimbangan alasan penolakan penghargaan tersebut antara lain, pertama, SPJ bukanlah sebuah bentuk pelayanan publik. Bahwa SPJ adalah sebuah gerakan rakyat di masa pandemi yang bertujuan untuk saling membantu sesama warga. Dalam konteks ini, nilai perjuangan SPJ adalah bentuk protes atas diskriminasi yang terus-menerus dilakukan oleh pemerintah terhadap kelompok-kelompok masyarakat rentan. Selain itu, SPJ bergerak atas kepercayaan bahwa rakyat dapat mewujudkan kemandiriannya melalui aksi-aksi solidaritas.

Kedua, SPJ bukan organisasi yang didukung oleh satu atau dua pihak pemilik modal besar yang menjadi pemimpin. Perlu diketahui, SPJ dihidupi oleh banyak orang dari lintas batas provinsi dan negara. Oleh karena itu, menurut SPJ penghargaan yang nyata seharusnya diberikan kepada seluruh rakyat Indonesia, yang saling membantu satu sama lain di masa sulit seperti saat pandemi Covid-19 demi kehidupannya. Ringkasnya, penghargaan yang perlu diberikan kepada publik adalah jaminan terhadap akses kebutuhan kesehatan, kesediaan pangan, pekerjaan, dan upah layak.

Ketiga, SPJ dapat bergerak karena adanya kepercayaan masyarakat dalam bentuk donasi uang, donator bahan makanan, kelompok relawan dan para petani yang secara rutin mengirimkan sayur dalam jumlah yang besar untuk dapur pangan di SPJ. Penolakan atas penghargaan dari pemerintah menegaskan bahwa gerakan SPJ sangat otonom, independen dan hanya berpihak kepada kelompok marjinal.

\subsection{Bersolidaritas dan Kemandirian Kolektif}


Dua instrumen yang biasanya diusung oleh kelompok gerakan sosial adalah, pertama merasa bahwa mereka dizalimi dalam aspek-aspek tertentu di dalam kehidupannya. Kedua, merasa optimis bahwa dengan bertindak secara kolektif mereka dapat mengatasi masalah yang diakibatkan kezaliman itu.

Meskipun demikian, dalam konteks tertentu kedua instrumen tersebut tidak selalu muncul bersamaan. Sehingga Snow menawarkan konsep 'framing process', yaitu situasi yang merujuk kepada upaya-upaya strategis yang dilakukan secara sadar oleh sekelompok orang untuk menampilkan pemahaman yang sama mengenai dunia dan diri mereka sendiri, yang melegitimasi dan memotivasi aksi-aksi kolektif (Snow et al., 1986).

Beberapa tahapan penting dalam 'framing process' antara lain, pertama, melakukan diagnosis suatu kondisi sosial yang bermasalah untuk dipecahkan. Kedua, menawarkan jalan keluar dari masalah itu. Ketiga, menawarkan alasan pembenar untuk memotivasi dukungan bagi aksi-aksi kolektif. Hal-hal tersebut penting untuk dilakukan untuk menjustifikasi, memuliakan, dan mendorong aksi kolektif (Tarrow, 2011).

Penggalangan donasi, penjualan cinderamata dan kolaborasi dengan beberapa organisasi lain seperti Paguyuban Petani Lahan Pantai (PPLP) Kulonprogo adalah manifestasi aktifnya jaringan sosial serta dukungan sosial kepada SPJ. Dalam dimensi TMSD, para pengelola gerakan (movement entrepreneurs) menawarkan insentif-insentif tertentu (Olson, 1965); material, solidaritas serta purposif, untuk memikat para aktor untuk bergabung dengan sebuah organisasi gerakan sosial. Hubungan yang harmonis melalui modal sosial tersebut menegaskan adanya perjumpaan visi kemanusiaan untuk saling membantu sebagai warga negara. Juga mengafirmasi konsep dalam TMSD bahwa komunitas-komunitas gerakan sosial memperlihatkan batas-batas yang cair, struktur kepemimpinan yang fleksibel, dan pembagian kerja yang lunak. Contoh serupa dapat dijumpai dalam elemen-elemen gerakan perempuan (Buechler, 1990). Situasi serupa juga sesuai dengan konsep Informal Security Regime, Wood (2004) dan Gough (2004) dalam kondisi ketika masyarakat kesulitan untuk memenuhi kesejahteraannya dari negara tau pasar, maka mereka akan mengandalkan peran akses sumber kesejahteraan yang lain seperti relasi keluarga dan pertemanan (Wood, 2004).

Sejalan dengan apa yang diuraikan (Sotiropoulos \& Bourikos, 2014) bahwa jaringan di SPJ telah membentuk ikatan informal baik di antara mereka maupun penerima manfaat dari kegiatannya. Selain itu, proses distribusi makanan di SPJ yang masif dan cepat memberi gambaran bahwa peran jaringan dukungan sosial dapat menjadi sebuah bentuk yang lebih signifikan dalam menolong kelompok rentan (Hill et al., 2020) dalam masa kesulitan ekonomi (Canton, 2018).

\section{Kesimpulan dan Saran}

Gerakan SPJ merupakan semangat advokasi untuk saling membantu sesama warga khususnya bagi kelompok rentan pada sektor informal di Yogyakarta. Kehadiran SPJ memberikan gambaran bahwa gerakan berbasis semangat 'rakyat bantu rakyat' selama masa pandemi sangat diperlukan sebagai alternatif ditengah kurang meratanya distribusi 
kesejahteraan sosial yang dilakukan oleh negara. Pola jaringan sosial yang dibangun oleh SPJ bersifat organik, yakni tumbuh dan berkembang berdasarkan kesamaan gagasan diantara kelompok sosial seperti aktivis, seniman, lembaga swadaya masyarakat, mahasiswa untuk menciptakan perubahan sosial yang lebih baik. Selain itu, gerakan SPJ juga ditopang oleh kelompok petani, misalnya organisasi PPLP Kulon Progo yang berkontribusi terhadap semakin menguatnya jaringan gerakan dalam wilayah advokasi sosialnya.

Akhirnya, tulisan ini menemukan bahwa secara tegas SPJ adalah gerakan yang sangat otonom dengan prinsip independensi. Wilayah kerja yang berbentuk pendampingan sosial serta bersifat sukarela (voluntary) merupakan konsep kunci yang menjelaskan gerakan ini tumbuh secara spontanitas. Kemudian menyebar melalui tumbuhnya kesadaran setiap individu dan kelompok yang merasa perlunya saling membantu di tengah krisis pangan selama masa pandemi Covid-19.

\section{Daftar Pustaka}

Ahmada, S. F., Marsetyo, F. D., \& Putri, R. A. (2020). Solidaritas Pangan Jogja sebagai Aktor Alternatif Penyedia Kesejahteraan di Masa Krisis Pandemi COVID-19. Journal of Social Development Studies, 1(2). https://doi.org/10.22146/jsds.524

Alkire, S., Dirksen, J., Nogales, R., \& Oldiges, C. (2020). Multidimensional Poverty and COVID-19 Risk Factors: A Rapid Overview of Interlinked Deprivations across 5.7 Billion People. OXFORD POVERTY AND HUMAN DEVELOPMENT INITIATIVE, April.

Barke, Peter. (1993). History and Social Theory. New York: Cornel University Press.

Canton, J. (2018). Coping with hard times: The role that support networks play for lone mother families in times of economic crisis and government austerity. In Families, Relationships and Societies (Vol. $7, \quad$ Issue 1 ). https://doi.org/10.1332/204674316X14651146433919

Haryadi, D., \& Malitasari, D. N. (2020). SOLIDARITY DURING COVID-19 PANDEMIC ( A CASE STUDY ON THE SOCIAL ACTION OF YOGYAKARTA FOOD SOLIDARITY AND THE INTERFAITH NETWORK FOR COVID-19 RESPONSE). Jurnal Partisipatoris, 2(2). https://doi.org/10.22219/jp.v2i2.12849

Hill, K., Hirsch, D., \& Davis, A. (2021). The role of social support networks in helping low income families through uncertain times. Social Policy and Society, 20(1). https://doi.org/10.1017/S1474746420000184

Moleong, L. J. (2019). Moleong, " Metodologi Penelitian Kualitatif Edisi Revisi”. Bandung: Remaja Rosdakarya. PT. Remaja Rosda Karya.

Sari, Y.I. Sisi Terang Pandemi Covid-19. (2020). Jurnal Ilmiah Hubungan Internasional, O(0). https://doi.org/10.26593/jihi.v0i0.3878.89-94

Snow, D. A., Rochford, E. B., Worden, S. K., \& Benford, R. D. (1986). Frame Alignment Processes, Micromobilization, and Movement Participation. American Sociological 
Review, 51(4). https://doi.org/10.2307/2095581

Sotiropoulos, D. A., \& Bourikos, D. (2014). Economic crisis, social solidarity and the voluntary sector in Greece. Journal of Power Politics \& Governance, 2(2).

Stolley, K. S. (2005). The Basics of Sociology. In Technometrics. https://doi.org/10.1198/tech.2003.s153

Sumner, A., Hoy, C., \& Ortiz-Juarez, E. (2020). Estimates of the impact of COVID-19 on global poverty. UNU WIDER Working Paper, April.

Suryahadi, A., al Izzati, R., \& Suryadarma, D. (2020). The Impact of COVID-19 Outbreak on Poverty: An Estimation for Indonesia (Draft). SMERU Working Paper, April(April).

Tarrow, S. (2011). Power in Movement. In Power in Movement. https://doi.org/10.1017/cbo9780511973529

Wiktorowicz, Q. (2004). Islamic activism: A social movement theory approach. In Islamic Activism: A Social Movement Theory Approach. https://doi.org/10.1177/009430610503400438

Wood, G. (2004). Informal security regimes: The strength of relationships. In Insecurity and Welfare Regimes in Asia, Africa and Latin America: Social Policy in Development Contexts. https://doi.org/10.1017/CBO9780511720239.004 